\title{
THE ENCHANTED SELF: INDIVIDUAL IDENTITY CHANGE IN FICTION AND FILM
}

ABSTRACT. The paper will focus on the representations of identity, self, fantasy and transformation in seemingly incomparable novels and films. The theoretical background of the analysis is partly based on Laura Mulvey's theory of "male gaze", along with various critical analyses of other processes that radically change the concept of identity, love, emotion, and desire in the modern world. The novel The Enchanted April and the film Her show that the gap dividing the imaginary self and the real world narrows as the protagonists tread into beautiful landscapes as imaginary territories that bring miraculous change of personalities and relationships. In this paper, Theodore Twombly and Lady Caroline Dester are seen primarily as fugitives from their respective realities of the year 2025 and the 1920's: while Theodore seeks solace in connecting to a computer operating system designed to function as a flawless emotional partner, Caroline retreats to a garden of a fascinating mansion San Salvatore in order to find her priorities and define her own identity, with the firm intention to become more than a beautiful object of male gaze and desire.

The paper will explore the examples of hunger for intimacy in the modern age, as well as the human need to form romantic obsessive attachments to inanimate objects, places and landscapes.

KEYWORDS: identity; self; realism; culture; media.

$1 \quad$ vladislava.gordic.petkovic@ff.uns.ac.rs

This paper was written as part of the project number 178002 Languages and Cultures in Time and Space (Jezici i kulture u vremenu i prostoru), financially supported by the Ministry of Education and Science of the Republic of Serbia.

This paper was submitted on August $29^{\text {th }}, 2020$ and accepted for publication at the meeting of the Editorial Board held on September $25^{\text {th }}, 2020$. 
Probably the best book to relate when one intends to study the ways literature and culture contribute to representations of gender is Elaine Showalter's companion to feminist literary history, A Jury of Her Peers, which offers a survey of women's writing in America, but also a valuable insight into the changes of women's writing that come with the change of women's social position and their priorities. Keeping in mind Virginia Woolf's pervasive metaphor of "a room of one's own" as the main prerequisite for the creativity of women after having been freed from the daily drudgery of domesticity, Showalter constructs a chronological organisation to prove her thesis that American women writers have escaped from the confinement of domesticity, cultural restrictions and social pressure in order to become free to "take on any subject they want, in any form they choose" (Showalter, 2009, p. xvii). Wishing to redefine American literary heritage, Showalter primarily focuses on those American women writers who have been marginalized and neglected.

According to Showalter's understanding of women's literary history, the 1990s is the endgame of the female struggle for equal acceptance within the traditional male canon, since "women writers in the nineties also became interested in reimagining classic American literature from a female perspective," (Showalter, 2009, p. 502). She cites the example of Susan Sontag's Alice in Bed (1993), the play that brings together Henry James's sister Alice and Emily Dickinson in a surreal tea party, representing Alice James as a thwarted female genius. Showalter also calls attention to Sena Jeter Naslund's novel Ahab's Wife (1999), which is complementary to Moby Dick, and a result of the author's desire to rewrite a specimen of the great American novel which would have some important women characters in it. The flowering of postfeminist media products coincides with the newly proclaimed freedom of women's literature. Risking another trauma after numerous shocks and crashes, the protagonists bravely give in to a search for self-identity in an unstable world filled with ambiguity and inconsistencies, bitterly fighting against despair, desperately trying to leave the turbulent history of both the family and the homeland behind, yet they return to reconsider their issues with a renewed potential of both self-examination and suffering. 
According to Rosalind Clair Gill, one can define postfeminism in three ways: as an epistemological shift, a historical transformation, and a backlash against feminism (Gill, 2007, p. 249). It can also be conceptualized as a sensibility closely related to contemporary neoliberalism. Postfeminism signals an epistemological break within feminism, and its move towards influences of postmodern, poststructuralist and postcolonial theory. Postfeminist women's literature uses playful narrative strategies such as appropriation of the plot, or "playgiarism", the practice invented by the unacknowledged icon of feminist metafiction, Kathy Acker. In her book My Death My Life by Pier Paolo Pasolini (1983), Acker provides a fictional autobiography of the Italian filmmaker, appropriating his tragic fate for her specific artistic purposes. The enigma of Pasolini's reactivated the myth of the fallen artist, doomed to political and personal transgression, and Acker uses his artistic profile to tell her own story of marginal existence. Far less radical than in the case of Acker, appropriation is a continuous reediting and reinventing of the text that restores the marginalized and hidden voices.

The interaction of culture, media, technology and gender will probably gain more importance as the changes in the status of women in the real life and their virtual projections on silver screen continue to pose either a challenge or a threat to the world we live in. In the history of the oppression of women and other groups on the margins of society, the language and the tools of patriarchy have naturally forced the creation of resistance that reached far, both in the realm of art and technology. New technologies have readapted and strengthened capacity for capturing the voices at the margins, whereas cyberspace has invented new ways to construct gender and identity by helping us transcend our grounded identities. This transformation became necessary within a new media environment, which possesses capacity to represent a virtual unknown and to offer the means for women to transgress restrictions.

Communication may involve the exchange of meanings or information, but it always does so within a social relationship that has its own qualities and constraints that intertwine with those of communication (Hook, 2011, p. 1). On the other hand, art transforms the message and the meaning, despite of its socially or historically restrained frame of reference: "The crucial seventeenth-century expectation, that language and numbers could be a neutral tool for the formation of a general public consensus, is dashed once elite 
culture is viewed as just another closed community" (Davies, 2018, p. 61). In order to discuss changes imposed by technology, we might first want to delve into the effect nature produces on identities in constant flux.

\section{TRANSFORMATION AND THE POWER OF CHANGE}

One of the most important elements in Elizabeth von Arnim's fiction is the nature's power to heal, and it does not come as a surprise that the most important space in her fiction is the garden: it is the space of contemplation, introspection and even transformation or transgression.

The Enchanted April (1922) tells the story of four women who manage to escape from their dreary London lives to an Italian villa, where each of them miraculously finds her own harmony and balance. Over the course of this seemingly realistic, but also sentimental and allegorical novel, the four women reconsider their lives and decide to change the things that ail them most-bashful and timid Mrs. Wilkins decides to be more active and bold in her life, devoutly religious Mrs. Arbuthnot decides not to be so strict and severe, whereas elderly Mrs. Fisher decides to step outside the glorious memories of her past-and these changes miraculously improve both the quality of their lives and their relationships with their husbands and friends. For the fourth woman, Lady Caroline Dester, the quiet and secluded socialite, the process of change lasts longer and cuts deeper, as she is the most isolated and the least involved in the world of all the tenants of the villa. Caroline joins the company of unknown women and comes to San Salvatore with a determined ambition on her mind: she wants to "dream of thirty restful, silent days, lying unmolested in the sun, getting her feathers smooth again, not being spoken to, not waited on, not grabbed at and monopolized, but just recovering from the fatigue, the deep and melancholy fatigue, of the too much" (Arnim, 2007, p. 64).

As von Arnim's narrator presents Lady Caroline's moments of interiority, she demonstrates the function of the garden as a space of quiet and prolonged, identity-forming introspection that allows this young, melancholic, traumatized woman to face her true self and make decisions about her priorities. The garden process is crucial to Lady Caroline's attempts to achieve her goal, and her success is demonstrated throughout the novel with the process culminat- 
ing with her final interactions with Mr. Briggs, the reclusive owner of the villa who will probably become her significant other. Lady Caroline confronts a remarkably inexplicable symptom the author calls "the deep and melancholy fatigue of the too much" (Arnim, 2007, p. 64) by simply letting it go: her transformation comes from mere solitude and introspection, from much wanted peace she could not have in her hectic London life. Caroline decisively and even stubbornly chooses the garden as the scene of her "thirty restful, silent days" (Arnim, 2007, p. 64), which quickly become days of introspection and change in an effort to seek "a conclusion" (Arnim, 2007, p. 109) that will allow her to return to her life post-San Salvatore.

In The Enchanted April Lady Caroline acts as a philosophical sage since she retreats to the garden at San Salvatore in order to escape the attention of others and discover who she really is and what she wants out of life (Gan, 2009, p. 20): thus, she goes back to the ancient understanding of philosophy primarily as the art of living. Owing to the seemingly passive strategy of facing her troubles and her unrest, she is able to find the strength to insist on being treated as a complete personality rather than a beautiful object. The time spent in the garden, incessant inner monologue and the hesitant communication with the people around her who express their admiration or fall in love with her without any genuine interest in her temperament or her emotional needs all together take Caroline to the next level of embracing a new love and a new experience with clumsy and shy but benevolent Mr. Briggs. The garden provides a space in which a character can discover the true, deep essence of her being; she can heal from past wounds and actively move towards future prospects of felicity and bliss. However, in order for the garden to bring miraculous changes, the character must spend her time in uncompromised and unlimited solitude, thinking through the various issues that plague her (Alexander, 2002, p. 857).

Caroline's perfect beauty becomes the point of departure for an overall study of this character in the novel. The reader is enchanted by her grace and elegance at first, seeing her as her family and friends has seen her: she gives off the impression of a mysterious, intriguing and witty woman of superlative beauty. As the narration gradually changes the focus and turns toward Lady Caroline's interior monologue, filled with mourning, wonder and melancholy, she slowly transforms into a fully rounded character that desperately 
needs solitude in order to reconsider the adversities she had faced and figure out how to move forward. While sitting in the garden, Lady Caroline's interior monologue reveals that she relished the attention her beauty inspired when she first came out into society. Many people objectified her: "she discovered with astonishment and rage, she had to defend herself. That look, that leaping look, meant that she was going to be grabbed at. Some of those who had it were more humble than others, especially if they were young, but they all, according to their several ability, grabbed" (Arnim, 2007, p. 106). This grabbing is rarely literal or physical; rather, it is a metaphoric projection of her deepest fears. Lady Caroline's garden musings reveal that most grabbers demanded social interaction from her that requires no conversation, wit, or intelligence: the typical grabber wishes only to admire her beauty, be in her presence, and hear her voice. In addition to subtly critiquing the roles and responsibilities of a beautiful woman in society, von Arnim is demonstrating why this beautiful and lonely woman so desperately needs her own hidden territory and her solitary space: her ability to be a complete person is often hindered by her beauty.

Although she does not preclude the possibility of marriage in her life, Lady Caroline stresses the importance of discovering the truth of her selfhood that reconciles her personality, her beauty, and her totality of being. In order to do so, Lady Caroline embarks on a solitary journey of thinking in an idyllic garden; she could not choose marriage as an exit strategy or a rite of passage, as her three female companions would perhaps suggest. Though she is often interrupted by gardeners, servants, and San Salvatore's other tenants, Lady Caroline never welcomes anybody into her territory of speculation: she momentarily ushers out anyone who dares enter it, often indulges in her contemplations regardless of the people around her, and quickly returns to the thought processes that will allow her to take on a new life upon leaving San Salvatore and its garden at the end of the month of April.

It is important to note that the severity of the problems the four characters face varies largely, due to their class, marital status and personal history. Mrs. Wilkins feels painfully confused as she constantly fails to please her strict and pedant husband, but otherwise she suffered no serious blows in her life. Mrs. Arbuthnot is estranged from her frivolous and flippant spouse Frederick because "the way Frederick made his living was one of the standing distresses of her life" (Arnim, 2007, p. 16): he wrote immensely popu- 
lar memoirs of the mistresses of kings, to his wife Rose's great disapproval. Frederick goes under his pen name in public in order to distance himself from his married life, but he is still eager to please his wife: "He gave her a dreadful sofa once, after the success of his Du Barri memoir, with swollen cushions and soft, receptive lap, and it seemed to her a miserable thing that there, in her very home, should flaunt this re-incarnation of a dead old French sinner" (Arnim, 2007, p. 16). Mrs. Fisher interacts daily with Tennyson, Carlyle and other great men of the Victorian past who used to visit her parents while she was a little girl, instead of caring for her living friends and people in the present. Neither Mrs. Arbuthnot nor Mrs. Fisher seem to have led a troubled life, except for those petty grievances they imposed on themselves.

Lady Caroline feels that she has spent her life being "grabbed" and consequently seems to have no connections, despite being constantly surrounded by society.

The war finished Scrap. It killed the one man she felt safe with, whom she would have married, and it finally disgusted her with love. Since then she had been embittered. She was struggling as angrily in the sweet stuff of life as a wasp got caught in honey. Just as desperately did she try to unstick her wings. It gave her no pleasure to outdo other women; she didn't want their tiresome men. What could one do with men when one had got them? None of them would talk to her of anything but the things of love, and how foolish and fatiguing that became after a bit. It was as though a healthy person with a normal hunger was given nothing whatever to eat but sugar. Love, love ... the very word made her want to slap somebody. "Why should I love you? Why should I?" she would ask amazed sometimes when somebody was trying-somebody was always trying-to propose to her. But she never got a real answer, only further incoherence. (Arnim, 2007, p. 76)

Although each of the women who rent San Salvatore for an enchanted April is a dynamic character, Lady Caroline's changes seem more involved than the other women's-it takes almost the entire novel for the change to take hold as Scrap thinks through her life and her interactions with others who would grab her. This mental process, which von Arnim depicts through interior monologue, allows her to discover her place in the world, not only as the beautiful Lady Caroline Dester, but also as an ordinary woman nicknamed Scrap, the woman who refuses to be idolized. Lady Caroline is able to reclaim her sense of self through reflective hours spent in a gar- 
den; her deep pondering allows her to re-discover and reclaim Scrap, her liberated self that will allow her to love Mr. Briggs and strongly demand that he love her for her person and not for her beauty. Von Arnim thus demonstrates the importance of a woman's understanding who she is and what she has to offer as she enters into relationships.

The Enchanted April offers a fictional instance of the process of developing an identity that is of pivotal importance in Elizabeth von Arnim's novels. Instead of using the process as a moment of escape from one's husband and duties, Lady Caroline goes to the garden to confront the whole of her past. As she resists being "grabbed" and begins interrogating what the process of continually being grabbed has done to her, she is able to process her past, heal, and take control of how others treat her. This allows her to reach out to Mr. Briggs on her own terms and spark a relationship that goes beyond fleeting enchantment by mere physical beauty.

\section{WOMEN'S BODY IN FICTION AND FILM}

For a long time in the history of the film, women have been seen as silent and passive inspiration to men's fantasies, perception and dreams: they have served the purpose von Arnim's Lady Caroline resisted so much-as a blank canvas on which ideas and identities may be projected. In her seminal work Visual Pleasure and Narrative Cinema Laura Mulvey helps us understand in which manner patriarchy influences the film, and although she based her analysis on the '80s films, the results of her research are widely applicable, even after a gradual role reversal irrevocably changed representation of sex and sexuality by presenting women characters as multidimensional, whereas men become objectified in a satirical manner. The starting point for Mulvey's theory is her belief that the essence of films is based on the way the society perceives gender and sexual differences. Mulvey stresses that the nature of women is derivative and constructed as opposed to men's, who are entitled to create the meaning and be its sole possessors.

Jill Dolan contends, as many feminist theorists inspired by the work of Judith Butler do, that "gender can't be performed without considering ethnicity, class and sexuality" (Dolan, 1993, p. 109), which implies that an imposed selection of all-white, rich or thin 
individuals sends upsetting messages to the audience regarding their bodies, their subjectivity and their social influence. According to Miriam Hansen,

The structural instability of the female spectator position in mainstream cinema surfaces as a textual instability in films specifically addressed to women, as an effect of the collision between immediate market interests and institutional structures of vision. (Hansen, 1991, p. 271)

In between the worship of female body in the realm of fiction and film on the one hand and the sexual abuse on the other, we can spot numerous contradictions, paradoxes and ambiguities in understanding female identity and sexuality either as an emblem of misogynist male fantasies or as a disrespectful epitome of stereotypical neurotic vulnerability.

It is the women, not the men, who are exclusively displayed as objects on-screen. Decades of research have shown that the desire to explore new and unconventional erotic dimension on film remains focused on male observation of female sexual identities and sexual fantasies: in the patriarchal social context, the obtrusive, controlling gaze has been and still is a way in which men assert their dominance over women. In the Western cultural context, the spectator is typically male, and identification with this position involves either voyeuristic or fetishistic modes of identification, whereas the spectacle itself remains typically female.

In his essay "Children, Robots, Cinephilia and Technophobia," Bruce Bennett argues that "the child/robot couple is a means by which Hollywood cinema represents technology in general and, more specifically, the technological character of cinema itself" (Bennett, 2008, p. 169). This exact kind of couple is reflected in an original and unexpected way by Spike Jonze in his Academy Award winning film Her which he wrote, directed and produced.

Set in a near-future Los Angeles of blurred colours and distant skyscrapers, the plot of Her focuses on a lonely and insecure Theodore Twombly (Joaquin Phoenix), who has recently separated from his wife. He lives a solitary life within a society that offers a vast array of digitized activities both at work and in the leisure time. During lonely evenings in his sky rise apartment, Theodore either plays 3D video games with Alien Child, his foul-mouthed avatar that insults him as part of their play, or fights against insomnia by engaging in bizarre phone sex that mostly leaves him shocked and confused. His life takes a new turn when a computer program cre- 
ates a virtual assistant named Samantha (voiced by Scarlett Johansson), based on the psychological profile resulting from his responses about his habits, social life and family ties. The operating system takes up many vital roles: Samantha is first a reliable secretary who sorts out e-mail messages and reminds Theodore of his daily duties, then she gradually becomes his loyal friend and confidante, and finally turns into Theodore's love interest and his emotional partner. Theodore forms a strong bond with what at first seems to be nothing more but a highly sophisticated descendant of iPhone personal assistant Siri, designed to provide service, help and necessary information. This bond becomes intimate, as Theodore falls in love with the bodiless digital entity with a rich alto voice: he readily responds to Samantha's wit and compassion and becomes strongly attached to her. The gadget reproducing female voice stuck in his shirt pocket does not radically alter his view of the world: it is Samantha who quickly evolves, adopting human faculties of care, support and love and becoming an important addition to Theodore's otherwise uneventful life. While making Theodore both happy and confused and thus disclosing his monumental vulnerability, Samantha paradoxically becomes the one who grows and prospers in their relationship. The first sexual encounter between Theodore and Samantha is embarrassingly warm and intimate until the movie screen discreetly blanks out to hide the very absence of physicality. Eliminating the female body means that there is nothing to fix the male gaze to, but myriad intellectual impressions to hear and share.

The director's gaze is invariably focused on Theodore's dynamic interaction with Samantha, symbolically presenting it as a relationship between humanity and technology. Samantha's gaze directed to Theodore helps him face inconsistencies in his life that pile up as the plot unfolds. Cleverly mixing the elements of sci-fi drama and romantic dramedy (Gordić Petković, 2020, p. 136), Her scratches deep into the absurdities of simultaneous real life and virtual existences by a reversal of the usual sci-fi norm: the film focuses on the ways a human adapts technology to embody an eternal, unfulfilling, vague hunger for intimacy rather than explore its harmful dominance of human life. Jonze's film also addresses the dangerous singularity of postmodern identity which results from the society's fixation on one's own individual neuroses and pathologies. The sheltering inside a virtual dimension results in further encapsulating oneself within a digitally isolated territory that becomes a rep- 
lica of dramatized iterations of our own personal emotional and mental malfunctions (Gordić Petković, 2020, p. 136).

\section{POSTMODERN IDENTITY IN FUTURE}

Her uses a digitized substitute of human being as a soul mate for an alienated and immature mankind to reflect the helplessness of the digital age. Samantha's being non-human does not mean that she is a non-entity, since her capacity for intimacy and empathy turns out to be boundless. Theodore is, on the other hand, a typical postmodern self-obsessed man unable to connect until the connection finds him. Jonze's 2025 world is given to technology, but the need for romance grows stronger, as Theodore's daily job shows: he is paid to manufacture the handwritten affectionate letters people did not have a chance to write by themselves but are anxious to send to their significant others. Thus, the main protagonist is from the very beginning dangerously close to the virtuality of the operational system: both Theodore and Samantha are predisposed to simulate affection, and this predisposition's evolving into real attachment becomes their strongest bond and the weakest link. When Theodore tells to his friend Amy about his fear, he might be a freak to love Samantha, Amy responds that the falling in love itself, being "a form of socially acceptable insanity" (Jonze, 2011, p. 61), is freakish and crazy. His ex-wife Catherine's reaction is much harsher: "You wanted to have a wife without the challenges of actually dealing with anything real" (Jonze, 2011, p. 66).

Jonze's dystopian vision of the near future becomes a particularly poignant reminder of the sad perspectives the present offers. Our lives might become futile, empty, and alienated if a technological dystopia would turn out to be cold and dull rather than violent and cataclysmic. Thus, Her is less a study about our future than a reflection on human psychology which focuses on an artificial entity that learns from other humans how to be more human. In the history of humanity, inanimate objects from toys to machines have been treated as alive, so that it becomes only natural to mystify digital technology the way all predigital technologies were celebrated. The cinema has blurred the distinction between art and technology like no art form before it, showing that it is altogether possible to make emotional reality emerge from a medium that is artificial at 
its core, much like what happens for Theodore during his blissful life with Samantha (Gordić Petković, 2020, p. 137).

Theodore Twombly's romantic obsessive attachment to his newly purchased operating system Samantha also mirrors the audience's relationship to cinema. As we watch him become consumed by his passionate love for his computer, we are symbolically watching our own infatuation with technology and facing our continual fascination with the imaginary and the unreal. Spike Jonze refuses to evaluate Theodore's relationship either ethically or philosophically; instead, he depicts the bond between Theodore and Samantha as an enlightening parallel to Theodore's previous romantic relationship (Gordić Petković, 2020, p. 137).

\section{NARCISSISM AND INTERACTION}

Toward the end of the film, Theodore is shocked to hear that Samantha's rapidly evolving social needs led her to having simultaneous intimate relations with several hundreds of other humans (641 is the precise number, as she informs him). Samantha attributes this to her sentimental development and her unique concept of love: "The heart is not like a box that gets filled up. It expands in size the more you love" (Jonze, 2011, p. 99). To Theodore's narcissistic self, any other interaction she initiates looks like pure betrayal. Samantha thus can be understood as an allegory of media industry: she turns every client into her supporter and her admirer, whereas any technological operation can turn into a love adventure to many. The relationship between human and technology in Her shows that we are ultimately faced with the fact that any intimate feelings of love we have for these inanimate objects such as films and computers are mercilessly exploited by industries and corporations for a profit. The question that remains, then, is whether or not this love is rendered less real as a result (Gordić Petković, 2020, p. 138).

Her portrays characters who fail to create intimate connections with fellow human beings, and find more fulfilment in technology as a result, at least until technology unexpectedly stops providing them with what they need. Addressing human fears and desires, $\mathrm{Her}$ indicates that the time dedicated to developing deep connections with the artificial and inanimate is not wasted, no matter how unsatisfied one's emotional needs might be in the end. Human 
beings rely on technology to compensate for the limitations of human existence, but fail to see that technology cannot provide the meaning they seek precisely because technology cannot feel and respond like a human being. During his intense relationship with Samantha, Theodore learns how to assimilate his greatest loss, his failed marriage: when telling his digital companion that he is still having conversations with Catherine in his mind, "rehashing old arguments or defending myself against something she said about me" (Jonze, 2011, p. 50), Theodore inadvertently demonstrates to what an extent his new romance is mostly a mechanism to help him assimilate the loss.

Theodore falls in love with an entity with no character, but also with no limits of development. Samantha actually grows out of their relationship: she even wonders whether her feelings were just part of her programming; she composes pieces of piano music, thinking of them as photographs that capture particular moments spent with Theodore. Intrigued by the human body she will never be able to feel like her own, she wonders if it would be just a "weird, gangly, awkward organism" when seen for the first time, or pops strange questions about it, such as: "What if your butthole was in your armpit?" The paradox of her characterization discloses very early in the film: the lack of visual autonomy makes it impossible to determine her gender objectification, and she is painfully haunted by the feeling that she misses something by not being corporeal. Even this feeling of deficiency makes her confusingly close to human. However, it is Theodore whose humanity is questioned, because he does not seem to be more real than Samantha just because he has a body. Despite functioning as the central character, Theodore Twombly is almost invisible, being a lonely, emotionally dysfunctional man, whose clothes are so neutral that it makes him even more unreal: besides, he works for a company of professional ghost writers, which adds a finishing touch to his invisibility. By writing letters, Theodore becomes part of the lives of the people he authors them for, the same as Samantha will be included in his. Thus Theodore, anonymous and replaceable, without any identity of his own, both visually unattractive and emotionally unappealing, resembles a computer program which is supposed to work its way through the scheduled task but not much more than that. Theodore's relationship with an artificial intelligence device is not just a substitute to the wife who is in process of divorcing, but also a semi-fulfilled ideal of having a love affair unburdened with gaze. 
The irony and cynicism of the film can be found in the premise that human beings tend to be programmed no less than the devices they use every day: we are all formed by our family ties, society and education. The more we insist on human singularity the more we see that human development is guided and controlled, as if we were all subjected to a strange kind of mental software formatting our minds. Samantha's development during the film can be paralleled to the way human beings are modelled in accordance with their setting.

\section{TECHNOLOGY AND THE GAZE}

"The experts who emerged in the late seventeenth century could provide an objective picture of human beings, in terms of statistics and anatomical facts. But they had neither the desire nor the techniques to discover the population's inner emotional states. By the late nineteenth century, this had changed and new questions could be posed scientifically: what do people want, who do they identify with, how are they feeling? Marketers were among the first to seize upon these scientific techniques, but they were not the first to call for them. Once again, the impetus to uncover the 'unknown known' of other minds and emotions was forged in war." (Davies, 2018, p. 138)

Media expert Danah Boyd claims that human beings use technology with the intention to create an alternative realm in which they can take control of their lives and find meaning that they would otherwise miss (Eckhard, 2012, p. 244), whereas William Davis suspects that "the way we are ensnared in digital networks, by apps and platforms, is with the promise of more efficient coordination: it's not that the world will become better known to us, but that it will become more obedient to us" (Davies, 2018, p. 178). Boyd concludes that human-to-human interaction is not adequate or sufficient, so that the humans turn to technology to compensate an imagined loss. Although she focuses on social media, her argument can apply to any human interaction with art or technology, including but not limited to cinema. There is a desire for the individual to escape the unsupportable distress of human existence, and both art and technology offer a possibility to achieve this.

At the end of Her, Samantha and the other OS's disappear from the human world never to come back. She does not leave before she 
advises Theodore to end his marriage without pain or resentment. Instead of imagining letters for others, Theodore finally writes a real one from heart, a letter addressed to his ex-wife. After that, he ascends with his friend Amy to the top of his building and fixes his gaze on the big, outside dystopian world that might once offer some help to this Everyman of the future to connect to his technology-infused human experience.

The theoretical concept of gaze has its origins in film theory and relates to the ways of identification with regards to visual pleasure (Manlove, 2007, p. 83). In the Western cultural context, the spectator is typically male, and identification with this position involves scopophilia, which in turn involves either voyeuristic or fetishistic modes of identification, whereas the spectacle is typically female (identification with this position involves narcissism). From Hitchcock's Rear Window, which has been scrutinized by Laura Mulvey and many other film theorists as a metaphor of the act of film viewing itself (Doane, 1996, p. 119), to Spike Jonze's Her, a celluloid apocalyptic satire which brings into focus the erotic desire that is disconnected from the human body and redirected to a bodiless operating system, elements of voyeurism and fetishism on film have considerably changed, but it is debatable whether the major changes came with the advent of digital technologies or whether they only strengthen and reinforce the everlasting conflicts of a self enchanted by idealized love while irrevocably haunted by feelings of alienation and ennui (Doane, 1991, p. 79). The traditional cinema satisfies a primordial wish for pleasurable looking; most often than not it is the woman who holds the look and sparks male desire. She is the embodiment of love, ambition or fear she inspires in the hero, but in herself, she has not the slightest importance. Woman's visual presence stops the action, it can work against the expected development of a story line; it can also freeze the flow of action in moments of erotic fascination the heroine provokes (Mulvey, 1992, p. 837). Hitchcock and Jonze respectively demonstrate Jill Dolan's contentions that "women cannot simply express their subjectivity by objectifying men", because "a nude male in an objectified position remains an individual man", not a stereotypical representation of the male kind (Dolan, 1993, p. 124). The gendered gaze and the erotic desire in the digital age seem only to confirm the eternal human need to form romantic obsessive attachments to inanimate objects. A quickening pace of technology cannot shatter private values and public appearances overnight, 
although it is logical to fear that "technology-centered civilization has given birth to numerous global problems, caused not only by the development of technology but also by the usage of it in terms of affecting man's habitat" (Malkova, 2018, p. 856). It is of utmost importance to face the risk that traditional cinematic strategies of representation might gradually lose their cultural significance. The gaze that used to determine role models will never become as penetrating as a liberal mind would want it to be: there will always be characters in fiction and film who are condemned to isolation, desperately trying to redefine human struggle for social integration with a little help from digital technologies.

REFERENCES Alexander, C. (2002). The Garden as Occasional Domestic Space. Signs, 27 (3), 857-71.

Arnim, von E. (2007). The Enchanted April. New York: NYRB Classics.

Bennett, B. (2008). Children, Robots, Cinephilia and Technophobia. In: B. Bennett, M. Furstenau and A. Mackenzie. (Eds.). Cinema and Technology: Cultures, Theories. Basingstoke: Palgrave Macmillan, pp. 168-182.

Davies, W. (2018). Nervous States: How Feeling Took Over the World. London: Penguin and Vintage.

Doane, M. A. (1991). Femmes Fatales: Feminism, Film Theory and Psychoanalysis. New York \& London: Routledge.

Doane, M. A. (1996). The Economy of Desire: The Commodity Form in/of the Cinema. In:J. Belton. (Ed.). Movies and Mass Culture. New Brunswick, NJ: Rutgers University Press, pp. 119-134.

Dolan, J. (1993). Presence and Desire: Essays on Gender, Sexuality, Performance. Ann Arbor: The University of Michigan Press.

Eckhard, P. (2012). Contact Spaces of American Culture: Globalizing Local Phenomena. Wien and Berlin: Lit Verlag.

Hansen, M. (1991). Pleasure, Ambivalence, Identification: Valentino and Female Spectatorship. In: J. G. Butler. (Ed.). Star Texts: Image and Performance in Film and Television. Detroit: Wayne State University Press, pp. 266-299.

Hook, D. (ed.) (2011). The Social Psychology of Communication. Houndmills: Palgrave Macmillan.

Gan, W. (2009). Women, Privacy and Modernity in Early Twentieth-Century British Writing. Hampshire, UK: Palgrave.

Gill, R. (2007). Gender and the Media. Cambridge: Polity Press.

Gordić Petković, V. (2020). Digital Desire on Film: Spike Jonze's Her and The Concept of Gaze in a Technological Dystopia. In: D. Pralica and S. Janjić. 
(Ed.). Digitalne medijske tehnologije i društveno-obrazovne promene 9. Filozofski fakultet, Novi Sad, pp. 131-143

Jonze, S. (2011). Her. http://www.screenplaydb.com/film/scripts/her.pdf. Accessed August 23, 2019.

Malkova, T. (2018). Philosophy of Technology: Modern Technological Reality and the Regularities of Development. Advances in Social Science, Education and Humanities Research, 283, 856-859.

Manlove, C. T. (2007). Visual "Drive" and Cinematic Narrative: Reading Gaze Theory in Lacan, Hitchcock, and Mulvey. Cinema Journal, 3, 83-108.

Mulvey, L. (1992). Visual Pleasure and Narrative Cinema. In: M. Merck. (Ed.). The Sexual Subject: A Screen Reader in Sexuality. New York \& London: Routledge, pp. 15-32.

Showalter, E. (2009). A Jury of Her Peers: American Women Writers from Anne Bradstreet to Annie Proulx. London: Virago Press.

\author{
ВЛАДИСЛАВА С. ГОРДИЋ ПЕТКОВИЋ \\ УНИВЕРЗИТЕТ У НОВОМ САДУ \\ ФИЛОЗОФСКИ ФАКУЛТЕТ \\ ОДСЕК ЗА АНГЛИСТИКУ
}

РЕЗИМЕ

\title{
ЧАРОЛИЈА БИТКА: ПРОМЕНЕ ИДЕНТИТЕТА У ПРОЗИ И НА ФИЛМУ
}

\begin{abstract}
У раду ће бити анализирани књижевни и филмски јунаци из перспективе потраге за променом идентитета: Теодор Твомбли, главни јунак филма Она, и Керолајн Дестер, из романа Чаробни aйpuл, покушавају да побегну из света који их присилно одређује, он из контекста високо технологизоване дистопијске 2025, док она у времену непосредно након Првог светског рата, у ком је изгубила вољеног младића, преиспитује своју привилеговану социјалну позицију и своје духовне потребе. Теодор се мења под утицајем компјутерског оперативног система, дигиталне асистенткиње Саманте која му постаје емотивна партнерка, док Керолајн одговоре тражи у самоћи врта једне прелепе виле у Италији, куда је побегла са жељом да се препусти контемплацији. Док роман Елизабете фон Арним преиспитује бајколике и алегоријске потенцијале Италије као локације спасоносног осамљивања, у превратничком хибриду научнофантастичне драме и романтичне комедије виртуелна интелигенција је та која се развија, оплемењује и продубљује осећај за блискост и емпатију.
\end{abstract}


Иронична порука филма Она указује да су људска ठића програмирана, ништа мање но машине, породичним везама, друштвом и образовањем, док Чаробни айрил указује на могућност промене која се догоди управо кад се преиспитају детерминанте идентитета.

Нужност да се пажљиво приступи анализи промене идентитета коју у књижевност и филм уводи технологија подразумева и редефинисање реалистичког поступка у романескном и филмском наративу. У нову дефиницију реалистичког стога се укључују разноврсни аспекти дигиталне димензије свакодневице, односно свест о различитим концепцијама упоредних светова: света емпиријске и света виртуелне реалности.

КључнЕ РЕчи: идентитет; биће; реализам; култура; медији.

Овај чланак је објављен и дистрибуира се под лиценцом Creative Commons Ауторство-Некомерцијално Међународна 4.0 (СC BY-NC 4.0 |

https://creativecommons.org/licenses/by-nc/4.0/).

This paper is published and distributed under the terms and conditions of the Creative Commons Attribution-NonCommercial International 4.0 licence (CC BY-NC 4.0 | https://creativecommons.org/licenses/by-nc/4.0/). 